\title{
GAMBARAN PENOLAKAN MASYARAKAT TERHADAP VAKSIN COVID-19 DI WILAYAH KAMPUNG DOYO BARU KABUPATEN JAYAPURA
}

Shania Carrity Virginia Woisiri dan Lyna Hutapea

Universitas Advent Indonesia

E-mail: woisirishania@gmail.com dan lynhutapea@gmail.com

\section{Diterima:}

09 November

2021

Direvisi:

13 November

2021

Disetujui:

15 November

2021

\section{Abstrak}

Latar Belakang : Gambaran penerimaan vaksinasi sangatlah kurang sehingga menyebabkan keterlambatan dalam mencapai herd immunity. Hasil telaah kepada masyarakat yang menerima vaksin yang dilakukan di bulan September 2020 oleh kementrian kesehatan menyatakan terdapat sekitar $65 \%$ subjek penelitian mengatakan setuju untuk di vaksin jika di sediakan oleh pemerintah, sedangkan $8 \%$ lainnya memilih untuk tidak menerima, serta 27 yang tersisa mengatakan masih ragu terhadap tindakan pemerintah untuk menyelenggarakan vaksinasi Covid-19. Organisasi kesehatan dunia mendefinisikan penolakan vaksin (VH) adalah sebagai penghambat dalam menerima atau menolak pemberian vaksin walaupun kegiatan vaksinasi tersedia di tempat terdekat dan gratis bagi masyarakat. Tujuan : Tujuan dari penelitian ini adalah untuk menggali serta mengetahui gambaran serta alasan dari masyarakat terhadap penolakan vaksin Covid-19 di wilayah Kampung Doyo baru Kabupaten Jayapura. Metode : Metode penelitian ini adalah penelitian dengan kualitatif dengan pendekatan studi etnografi. Penelitian ini dilakukan di Kampung Doyo Baru Kabupaten Jayapura. Pengambilan subjek dalam penelitian ini dilakukan dengan menggunakan cara atau metode purposive sampling. Subjek dalam penelitian ini adalah masyarakat kampung Doyo Baru yang menolak atau belum menerima vaksin covid-19 yang berjumlah 24 orang dengan kriteria inklusi : (1) Masyarakat yang tidak mau dan/atau belum menerima vaksin covid-19; (2) Berdomisili di Kampung Doyo Baru Kabupaten Jayapura; (3) Bersedia untung diwawancarai dan menjadi responden (dengan menunjukan surat pernyataan yang ditandatangani bahwa subjek bersedia tanpa paksaan untuk menjadi subjek penelitian); dan (4) Mampu berkomunikasi dengan baik. Hasil : Setelah peneliti mengumpulkan data di temukan hanya terdapat 6 dari 24 subjek yang mengetahui manfaat vaksin yaitu untuk kekebalan tubuh dan untuk melindungi diri sendiri dan orang lain dari paparan virus Corona. Terdapat 4 orang subjek yang mengatakan bahwa vaksin Covid-19 mengandung bahan yang haram menurut keyakinan mereka, sedangkan subjek yang lain masih merasa ragu atas keefektifan dari vaksin Covid-19 setelah mendengar issu yang beredar dan ada juga yang memilih untuk menolak vaksinasi karena adanya larangan dari orang tua dan anggota keluarga lainnya bahkan masyarakat sekitar lainnya.

Kata kunci: Penolakan masyarakat, vaksin Covid-19, 


\title{
Doyo Baru
}

\begin{abstract}
Background: The picture of vaccination acceptance is so lacking that it causes delays in achieving herd immunity. The results of a study to people who received the vaccine conducted in September 2020 by the ministry of health stated that about $65 \%$ of the study subjects said they agreed to be vaccinated if provided by the government, while $8 \%$ chose not to receive it, and the remaining 27 said they were still doubtful about the government's action to administer the Covid-19 vaccination. The World Health Organization defines vaccine rejection $(\mathrm{VH})$ as an obstacle to receiving or rejecting vaccines even though vaccination activities are available nearby and free to the public. Purpose: The purpose of this study is to explore and find out the picture and reason of the community against the rejection of the Covid-19 vaccine in the new Kampung Doyo area of Jayapura Regency. Method: This research method is qualitative research with ethnographic study approach. This research was conducted in Kampung Doyo Baru Jayapura Regency. The taking of subjects in this study was done using purposive sampling methods or methods. The subjects in this study were the people of Doyo Baru village who refused or had not received the covid19 vaccine which amounted to 24 people with inclusion criteria: (1) People who did not want and / or had not received the covid19 vaccine; (2) Domiciled in Kampung Doyo Baru Jayapura Regency; (3) Willing to be interviewed and be a respondent (by showing a signed affidavit that the subject is willing without compulsion to be the subject of the study); (4) Able to communicate well. Results: After researchers collected data found that only 6 out of 24 subjects knew the benefits of vaccines, namely for immunity and to protect themselves and others from exposure to the coronavirus. There were 4 subjects who said that the Covid-19 vaccine contained illegal ingredients according to their beliefs, while other subjects still doubted the effectiveness of the Covid-19 vaccine after hearing about the circulating issu and there were also those who chose to refuse vaccinations because of the ban from parents and other family members and even other surrounding communities.
\end{abstract}

Keyword: Penolakan masyarakat, vaksin Covid-19,Doyo Baru

\section{Pendahuluan}

Vaksin adalah jalan keluar terakhir untuk penyakit yang menular dengan droplet (percikan), halangan utama penggunaan vaksin Covid-19 adalah keraguan dan ketidak percayaan masyarakat terhadap vaksin. Stigma dari masyarakat masyarakat tentang keamanan dan efektifitas vaksin Covid-19 harus baik. Terdapat banyak rintangan dalam upaya menanggulangi pencapaian vaksinasi khususnya di ASEAN antara lain karena 
adanya penolakan vaksin /vaccine hesitancy $(\mathrm{VH}) /$ vaccine refusal. Aksi penolakan vaksin terjadi secara global. Banyak negara membuat gerakan penolakan karena beranggapan bahwa vaksin tidak efektif. Jumlah masyarakat yang menerima vaksinasi COVID-19 menjadi hal yang sangat kontroversi. (Astuti, Nugroho, Lattu, Potempu, \& Swandana, 2021). Strategi yang digunakan dalam pemenuhan vaksin pada masyarakat di Indonesia dihadapkan pada tantangan aksi vaccine refusal. Pada tahap awal pemberian vaksinasi COVID-19 beberapa kelompok yang tidak menerima vaksin membuat suatu kelompok antivaksin dalam bentuk menolak vaksinasi di media sosial (medsos). Penolakan tersebut juga di tolak oleh salah seorang Dewan Perwakilan Rakyat Republik Indonesia (DPRRI) yang memperkuat kelompok tersebut untuktidak menerima vaksin (Maulana1, 2021). Adapun minimnya kabar atau berita yang dterima masyarakat serta kurangnya sikap antisipasi pemerintah untuk memberikan edukasi terkait Vaksinasi mengakibatkan adanya penolakan masyarakat terhadap vaksin COVID-19. Kehadiran virus jenis baru yang belum ditemukan obatnya ini membuat masyarakat cemas, ketakutan, dan bahkan depresi. Komisi IX DPR RI melalui Rapat Kerja Bersama Kemenristek/BRIN, Kementrian Kesehatan, Badan POM serta PT Bio.Farma (Persero) Pada 14 Juli 2020 dalam Produksi dan pembuatan vaksin di Indonesi juga turut mendapatkan support . Vaksin juga sangat penting dan bermanfaat kepada semua orang. Ketika kita menerima vaksin, kita tidak hanya melindungi diri sendiri tetapi orang lain juga dapat terlindung dari penyakit infeksi yang berbahaya bahkan penyakit yang membawa kematian. Berdasarkan organisasi kesehatan dunia , kurang lebih sekitar 10 juta angka kematian di dunia berhasil tanggulangu dengan adanya vaksinisasi pada tahun 2010-2015 (Agustiarasari et al., 2021). Rencana kegiatan vaksinasi tersebut haruslah mempertimbangkan segala aspek, mulai dari aspek kelayakan vaksin yang akan digunakan, resiko pasca pemakaian, sampai tahapan \& prosedur dari pemberian vaksin hingga nantinya sampai ke masyarakat. Semua aspek tersebut haruslah dipersiapkan secara detail agar rencana aktivitas vaksinasi dapat berjalan dengan baik dan terhindar dari hal-hal yang justru akan merugikan.intervensi dari aktivitas vaksinasi juga perlu mempertimbangkan berbagai factor , diantaranya adalah dengan melihat bagaimana reaksi dan pendapat masyarakat terhadap rencana vaksinasi tersebut. Masyarakat Papua adalah masyarakat yang sangat menjaga budaya mereka, dan di dalam menjaga budaya tersebut menurut Tilaar (2004: 257) tersimpan hal yang sangat besar yaitu kapital budaya berupa anekaragam adat isti-adat, keyakinan, bahasa atau dialeg, dan system pemenuhan kebutuhan hidup (Kadir, 2017). Sehingga beberapa suku dan adat istiadat melarang untuk menerima vaksin Covid-19. Melihat adanya penolakan yang dilakukan masyarakat terhadap vaksin Covid-19 dan pemerintah yang kurang sigap dalam memberikan pendidikan kesehatan terkait vaksinasi kepada masyarakat khusnya masyarakat yang tinggal di wilayah Kampung Doyo Baru Kabupaten Jayapura yang masih hidup dengan adat-istiadat yang kental menyebabkan timbulnya opini-opini negative dari masyarakat terhadap vaksin Covid-19. Penelitian ini dilakukan agar dapat mengetahui dan menggali alasan serta gambaran penolakan masyarakat terhadap vaksin Covid-19 serta bermanfaat dalam membuka wawasan masyarakat terhadap vaksin Covid-19 dan menjadi tempat peneliti mengaplikasikan pelajaran yang telah diperoleh. Oleh karena itu peneliti tertarik untuk membahas gambaran penolakan masyarakat terhadap vaksin covid-19 di wilayah Kampung Doyo Baru Kabupaten Jayapura dan dengan penelitian ini diharapkan pemerintah dapat memperhatikan masyarakat dengan di adakannya pendidikan kesehatan tentang vaksinasi kepada masyarakat mengenai vaksin Covid-19 sebelum pengadaan kegiatan vaksinasi di suatu daerah. 


\section{Metode Penelitian}

Jenis yang digunakan dalam penelitian ini adalah penelitian kualitatif dengan pendekatan studi etnografi. Kegiatan ini dilakukan di Kampung Doyo Baru Kabupaten Jayapura. Pemilihan responden dalam penelitian ini dilakukan dengan menggunakan metode purposive sampling. Instrument yang digunakan dalam penelitian ini adalah berupa lembar wawancara dan voice recorder yang digunakan peneliti untuk merekam suara saat melakukan wawancara dengan subjek. Pertanyaan-pertanyaan yang digunakan peneliti telah di uji validitas melalui wawancara mendalam pada subjek triangulasi. Subjek dalam penelitian ini adalah masyarakat yang menolak vaksin covid-19 yang berjumlah 24 orang dengan kriteria inklusi: (1) Masyarakat yang tidak mau /atau belum menerima vaksin covid-19; (2) memiliki alamat berdasarkan KTP di Kampung Doyo Baru Kabupaten Jayapura; (3) Bersedia untung di wawancara dan menjadi responden (ditunjukan dengan surat ketersediaan Subjek Penelitian yang ditandatangani oleh subjek penelitian); dan (4) Mampu berkomunikasi menggunakan bahasa Indonesia dengan baik. Pengambilan data dilakukan dengan wawancara mendalam dengan subjek penelitian. Wawancara mendalam juga di lakukan pada subjek triangulasi untuk uji validitas. Adapun subjek triangulasi dalam penelitian ini yaitu tokoh agama serta RT dan RW dari Kampung Doyo Baru Kabupaten Jayapura.

Penelitian menggunakan 2 teori antara theory of reason action, Sikap berfokus terhadap pendapat seseorang (baik menguntungkan maupun merugikan) dengan sikap tertentu (Saraswati \& Kiswara, 2013). Aturan subjektif berfokus pada penilaian seseorang akan hak lain dan support dalam berpendapat. Theory of Reasoned Action di komentar karena keteledoran terhadap pentingnya faktor-faktor sosial yang dalam kehidupan nyata bisa menjadi determinan terhadap sikap seseorang (Mahyarni, 2013). Faktor sosial artinya segala pengaruh yang datang dari lingkungan tempat tinggal sekitar (seperti norma individu) dimana dapat berpengaruh terhdap tindakan seseorang (Darmawan, Made, \& Warmika, 2016). Factor lain yang turut menentukan tindakan dan perilaku seseorang pada teori tindakan yang direncanakan yaitu perilaku kontrol yang dirasakan. Social cognitive theory dimana kebudayaan sebagai system kognitif atau pengetahuan (mode of), budaya merupakan sesuatu yang dilakukan individu dalam kehidupan stiap hari sebagai sesuatu yang realitas (Laila, 2017).

\section{Hasil dan Pembahasan}

Berdasarkan hasil penelitian yang di buat oleh organisasi kesehatan dunia (WHO), di nyatakan sebagian subjek tidak menerima vaksin dan kurang yakin terhadap intervensi dari pemerintah tentang kegiatan vaksinasi (5). Aksi penolakan vaksin COVID-19 menjadi hal penghambat yang perlu di cegah sehingga pencapaian vaksin COVID-19 dapat berjalan sesuai tujuan dari pemerintah sebagai usaha mengurangi penyebaran dan peningkatan penyakit COVID-19 .

$$
\begin{aligned}
& \text { “...vaksin itu kita tidak tahu } \\
& \text { jadi kita Kristen jadi kuat } \\
& \text { karena ada Tuhan jadi tidak } \\
& \text { mau vaksin, takut.." }
\end{aligned}
$$


Minimnya pengetahuan pada masyarakat menyebabkan masyarakat tidak memiliki pemahaman-pemahaman mengenai vaksin Covid-19. Masyarakat juga memiliki keterbatasan dalam mengakses internet guna mengetahui manfaat dan pentingnya vaksinasi menyebab minimnya pengetahuan masyarakat akan peran penting vaksin Covid-19 dalam melindungi diri sendiri dan orang lain di sekitarnya. Oleh karena itu pendidikan kesehatan mengenai vaksinasi kepada masyarakat sangatlah penting guna membuka dan mengubah sudut pandang masyarakat terhadap vaksin Covid-19.

\section{Sikap subjek penelitian terhadap vaksin Covid-19}

Berdasarkan hasil wawancara diketahui bahwa hanya 6 dari 24 subjek penelitian mengetahui tentang manfaat vaksin Covid-19 yaitu untuk meningkatkan daya tahan tubuh dan memproteksi atau melindungi diri dari penyakit. Sedangkan 4 dari 24 subjek penelitian mengharamkan vaksin Covid-19 karena masih krang yakin dengan kehalalan dari bahan yang digunakan dalam pembuatan vaksin Covid-19. Subjek penelitian juga masih dipengaruhi oleh apa yang mereka dengar melalui orang-orang di sekitar dan oleh berita-berita yang mereka dengar. Dan walaupun tidak menerima vaksin Covid-19, masyarakat beranggapan bahwa mereka akan tetap sehat karena mereka merupakan masyarakat yang terbiasa hidup melalui hasil tangan sendiri dengan berkebun sehingga mereka memiliki tubuh yang kuat dan sehat.

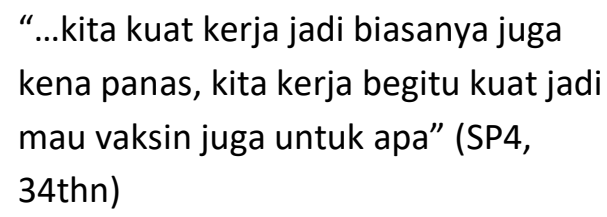

\section{Pengetahuan}

Masyarakat beranggapan bahwa seseorang biasanya cukup memiliki pertimbangan yang logis dan memanfaatkan berita serta seseorang akan memikirkan sebab-akibat dari perilakunya sebelum memilihmelakukan suatu tindangan. Setelah melihat semua penelitian yang sudah dilakukan oleh para expert sebelumnya, mereka mengembangkan teori yang dapat memperkirakan dan mengerti perilaku dan sikap. Teori ini yang disebut Theory of Reasoned Action.

Berdasarkan hasil wawancara diketahui bahwa hanya 6 dari 24 subjek penelitian mengetahui tentang manfaat vaksin Covid-19 untuk meningkatkan daya tahan tubuh dan memproteksi diri dari penyakit. Namun mereka ragu untuk menerima vaksin karena pengalaman yang di alami oleh orang-orang yang disekitar mereka yang sakit bahkan meninggal dunia setelah menerima vaksin Covid-19.

$$
\begin{aligned}
& \text { “...yang saya ketahui , hmm melihat } \\
& \text { cukup banyak masyarakat yang terlibat } \\
& \text { dalam vaksin mereka berkata bahwa } \\
& \text { dengan vaksin dapat memberikan } \\
& \text { kekebalan tubuh bagi setiap orang untuk } \\
& \text { menghadapi sakit Corona” (SP3, 45thn) }
\end{aligned}
$$


Beberapa subjek berjumlah 18 orang tidak mengetahui manfaat dari vaksin Covid19 sedangkan 6 orang lainnya menyatakan manfaat vaksin Covid-19.

“...Yahh untuk melindungi diri dari virus

Corona"(SP2, 21thn)

\section{Religius}

Dalam "theory of reasoned action" mengatakan bahwa aturan subjektif adalah determinan dari keinginan bertindak. aturan subjektif merupakan traktat sosial yang mengontrol kehidupan setiap individu. Aturan subjektif merupakan satu fungsi kepercayaan seseorang dalam hal menyetujui atau tidak menyetujui tindakan tertentu.

Terdapat pandangan yang berbeda terhadap vaksin Covid-19 dari segi agama. Terdapat 20 orang subjek penelitian yang menyatakan bahwa boleh menerima vaksin dan agama tidak mengharamkan vaksin Covid-19 karena kegiatan vaksinasi adalah kegiatan yang baik untuk kesehatan semua masyarakat dalam upaya melindungi diri dari paparan virus covid-19. Sedangkan 4 orang lainnya percaya bahwa vaksin Cocid-19 haram karena masih ragu dengan kehalalan dari bahan yang digunakan untuk membuat vaksin Covid19. Sehingga mereka memilih untuk tidak menerima vaksin.

$$
\begin{aligned}
& \text { “...oh iya, ini vaksin yang saya dengar hmm } \\
& \text { terbuat dari lemak babi dan agama saya } \\
& \text { bertentangan dengan daging babi karena } \\
& \text { menurut kami adalah haram. Sehingga } \\
& \text { kalau lemak babi di suntikan kedalam } \\
& \text { tubuh kami, maka kami juga mempunyai } \\
& \text { kesalahan yang besar dengan iman yang } \\
& \text { kami yakini” (SP3, 45thn) }
\end{aligned}
$$

MUI menguatkan vaksin Covid-19 produksi Sinovac dan Bio Farma suci dan halal serta dapat digunakan untuk masyarakat penganut agama Islam dalam keputusan Nomor 2 Tahun 2021 (Abdullah, 2021). Dan ternyata beberapa subjek penelitian tidak mengetahui keputusan tersebut.

\section{Keyakinan Subjek Penelitian}

Kepercayaan yang di yakini oleh responden dalam penelitian di pengaruhi oleh pengalaman vaksinasi yang di alami oleh orang di sekitar subjek dan melalui pembacaan berita-berita di TV yang membahas tentang orang-orang yang sakit,lumpuh atau bahkan meninggal dunia setelah menerima vaksin Covid-19. 
“...kalau di lihat dari tanggapan banyak

orang ada yang bilang bahwa vaksin itu

bisa membawa kematian" (SP2,21thn)

Kurangnya fasilitas yang memadai sangat mempengaruhi pengetahuan dari masyarakat yang hidup di daerah terpencil menyebabkan masyarakat sulit untuk mendeteksi penyakit bawaan (komorbid) sedini mungkin.

Berita yang salah tentang COVID-19 yang telah tersebar ke seluruh media, sangat penting bagi NAKES dan pemerintah dalam membuat intervensi dan strategi yang efektif sebelum vaksin diperkenalkan (Dharma \& Kasim, 2021).

\section{Larangan dari lingkungan masyarakat untuk menerima vaksin Covid-19}

Mengenai pengaruh sekitar keluarga adalah hal yang sangat berpengaruh terhadap keputusan seseorang, individu akan bertindak jika pendapat orang lain terhadap sikap itu bersifat positif (Dewi, 2020). Seseorang berpendapat bahwa sikap seseorang tersebutdi izinkan atau sebaliknya tidak di izinkan.

Diketahui bahwa 20 orang subjek penelitian mengatakan bahwa tidak ada larangan dalam menerima vaksin Covid-19. Sedangkan 4 orang subjek penelitian mengatakan adanya larangan dari keluarga dan orang-orang terdekat untuk tidak menerima vaksin Covid-19.

$$
\begin{aligned}
& \text { "...iya ada larangan dari keluarga jadi sa } \\
& \text { (saya) tidak vaksin" }\left(\mathrm{SP} 7,19^{\text {th }}\right)
\end{aligned}
$$

\section{Sikap subjek penelitian terhadap vaksin Covid-19}

Penolakan masyarakat pada vaksin Covid-19 dikarenakan kekeliriuan dan kesalahpahaman masyarakat pada vaksin Covid-19. Subjek penelitian beranggapan bahwa vaksin Covid-19 haram karena mengandung Babi. Sebelumnya, Komisi kepeutusan telah menegaskan kehalalan dan kesucian vaksin melalui siding pleno pada Jumat (8/1/2021). Beberapa subjek penelitian lebih memilih untuk menggunakan obatobatan herbal dalam mendukung dan menjaga kesehatan mereka.

\section{Pengetahuan}

Manfaat imunisasi yang di ketahui 6 dari 24 orang subjek penelitian tentang manfaat vaksin Covid-19 untuk meningkatkan daya tahan tubuh dan memproteksi atau melindungi diri dari penyakit (Matuan, 2021). Namun mereka ragu untuk menerima vaksin karena pengalaman yang di alami oleh orang-orang yang disekitar mereka yang sakit setelah menerima vaksin Covid-19.

\section{Religiuitas}

Masih terdapat subjek penelitian yang berpendapat bahwa vaksin Covid-19 mengandung babi., MUI mengatakan vaksin Covid-19 produksi Sinovac dan Bio Farma suci dan halal dapat digunakan untuk umat Islam dalam keputusan Nomor 2 Tahun 2021 (Chodir, 2021). Berdasarkan hasil dalam keputusan nomor 2 tahun 2021, MUI dapat 
berarti bahwa vaksin Covid-19 halal yang artinya tidak mengandung babi seperti yang di pikirkan oleh subjek dalam penelitian ini.

\section{Keyakinan subjek penelitian}

Aturan subyektif menrujuk pada tanggapan masyarakat sekitar (social) yang dirasakan untuk melakukan atau tidak melakukan, (Ajzen, 1991). Aturan subjektif adalah kepercayaan normatif terkait pada pendapat seseorang tentang bagaimana kelompok melihat tindakan dan evaluasi yang pada umumnya cetuskan . Persepsi dari masyarakat sekitar menyebabkan subjek ragu bahkan takut untuk menerima vaksin Covid-19.

\section{Larangan dari lingkungan masyarakat untuk menerima vaksin Covid-19}

Peran keluarga semakin instrumental dalam kehidupan berbangsa dan bernegara. Keluarga merupakan garda terdepan yang menjadi subsistem fundamental yang paling diperhitungkan Pemerintah dalam memutus mata rantai penularan Covid-19 (Husaidah, Amru, Selvia, Rahayu, \& Yulinawati, 2021). Peran fungsional kepala keluarga dimasa pandemic Covid-19 adalah kemampuan mendisiplinkan seluruh perilaku anggota keluarganya. Sama halnya dalam penerimaan vaksin Covid-19 keluarga juga memiliki peran yang besar dalam menentukan hal terbaik bagi anggota keluarganya (Santika, 2020).

\section{Kesimpulan}

Penolakan yang di lakukan masyarakat terhadap vaksin Covid-19 disebabkan kekurangan fasilitas yang memadai di kalangan masyarakat untuk mengetahui manfaat vaksinasi. Dan dalam mengangani masalah yang di hadapi masyarakat yaitu, diperlukan dukungan pemerintah dan pemimpin kampung atau desa setempat dalam memberikan pendidikan mengenai vaksin Covid-19 contohnya : apa itu vaksin Covid-19, apa manfaat vaksin, apa efek samping dari vaksin, apa yang perlu di perhatikan atau ketahui terlebih dahulu sebelum menerima vaksin Covid-19 terlebih dahulu agar dapat membuka wawasan masyarakat dan menghilangkan keraguan masyarakat terhadap vaksin Covid-19 dan meningkatkan kepercayaan masyarakat terhadap pentingnya vaksinasi dalam memproteksi diri sendiri dan orang lain dari paparan virus Corona mengingat masyarakat sangat di pengaruhi oleh budaya setempat sehingga di perlukan peran dari pemimpin kampung atau desa setempat dan tokoh adat yang di angggap berpengaruh oleh masyarakat sehinggah dapat mencapai herd immunity di wilayah Kampung Doyo Baru Kabupaten Jayapura.

\section{Bibliografi}

Abdullah, Farhat. (2021). Sinovac Vaccine Halal Controllers: According To The Lay Community. Tahdzib Al-Akhlaq: Jurnal Pendidikan Islam, 4(1), 13-27.

Agustiarasari, Bella Putri, Monica, Dila, Jordan, Muhammad, Risky, Muhammad, Arsika, Poppy, Syari, Rafita, \& Nursapitri, Rizki. (2021). Pentingnya Pengenalan Vaksin Di Masa Pandemi Covid-19 Desa Ibul Kecamatan Simpang Teritip. Jurnal Abdimas Bina Bangsa, 2(1), 100-104.

Astuti, Nining Puji, Nugroho, Erlangga Galih Zulva, Lattu, Joma Chyntia, Potempu, Imelzy Riana, \& Swandana, Dewi Anggiani. (2021). Persepsi Masyarakat terhadap Penerimaan Vaksinasi Covid-19: Literature Review. Jurnal Keperawatan, 13(3), 569-580.

Chodir, Fatkul. (2021). Kehalalan Vaksin Berunsur Babi:(Studi Vaksin Covid-19 
Astrazeneka). Jurnal Kajian Hukum Islam, 8(1), 61-81.

Darmawan, Yudi, Made, I., \& Warmika, I. Gede Ketut. (2016). Pengaruh Norma Subjektif, Personal Attitude, Perceived Behavior Control, dan Aspek Psikologis Terhadap Minat Wirausaha (Entrepreneurial Intention). Bali: Udayana University.

Dewi, Putu Yulia Angga. (2020). Perilaku School Bullying Pada Siswa Sekolah Dasar. Edukasi: Jurnal Pendidikan Dasar, 1(1), 39-48.

Dharma, Alexander Arie Sanata, \& Kasim, Azhar. (2021). Infodemi Covid-19 dalam Perspektif Open Government: Sebuah Tinjauan Literatur. JIIP: Jurnal Ilmiah Ilmu Pemerintahan, 6(1), 105-125.

Husaidah, Siti, Amru, Desi Ernita, Selvia, Anisya, Rahayu, Mona, \& Yulinawati, Catur. (2021). Handling Families Affected by Covid-19 on Panjang Island, Batam City: Penanggulangan Keluarga Terdampak Covid-19 Di Pulau Panjang Kota Batam. Ahmar Metakarya: Jurnal Pengabdian Masyarakat, 1(1), 6-13.

Kadir, Akhmad. (2017). Melihat Indonesia dari Jendela Papua: Kebinekaan dalam Rajutan Budaya Melanesia. JSW (Jurnal Sosiologi Walisongo), 1(2), 225-246.

Mahyarni, Mahyarni. (2013). Theory of reasoned action dan theory of planned behavior (Sebuah kajian historis tentang perilaku). Jurnal El-Riyasah, 4(1), 13-23.

Matuan, Ayub. (2021). Faktor Yang Mempengaruhi Pemberian Imunisasi Dasar Pada Bayi Di Puskesmas Popukoba Kabupaten Jayawijaya, Papua= Factors Affecting Giving Basic Immunization In Infants At Puskesmas Popukoba, Jayawijaya Regency Papua. makassar: Universitas Hasanuddin.

Mursinah, Mursinah, Susanti, Nike, \& Herna, Herna. (2020). Penolakan Vaksin di Beberapa Negara Asia dan Ancaman Penyakit yang Dapat Dicegah Dengan Imunisasi. SINASIS (Seminar Nasional Sains), 1(1).

Riptiono, Sulis. (2017). Hasrat Konsumen Yang Mengikat (Binding Customer Desires). Fokus Bisnis: Media Pengkajian Manajemen Dan Akuntansi, 16(2), 82-92.

Santika, I. Gusti Ngurah Ngurah. (2020). Optimalisasi Peran Keluarga Dalam Menghadapi Persoalan Covid-19: Sebuah Kajian Literatur. Jurnal Ilmiah Ilmu Sosial, 6(2), 127-137.

Saraswati, Prita, \& Kiswara, Endang. (2013). Analisis Terhadap Penerapan Theory Of Consumer Acceptance Technology Pada E-Spt. Fakultas Ekonomika dan Bisnis.

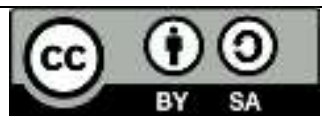

This work is licensed under a Creative Commons Attribution-ShareAlike 4.0 International License. 